\title{
The Innovation of Art Design Education under the Influence of New Situation
}

\author{
Yonghua Jing \\ Minsheng College \\ Henan University \\ Kaifeng, China, 475004
}

\begin{abstract}
In the increasingly competitive society and under the present situation of the social and economic booming period, in order to make students adapt to the current social development and put their learning into application, the practicebased reform for cultivating skill-purposed talent should be performed, through the combination of class and field, to achieve the new mode of practical skills operation promoting academic teaching. The reform will make the students understand and participate in the production and management of enterprises while they study in school, make the student more social and let their program orientation in line with the social development, so as to meet the needs of enterprise for development. The effective operation of practice-based teaching mode of arts design, will ensure good operation of design education teaching system. It will fully drive the enthusiasm of both school and enterprise, so as to bring win-win situation for both of them.
\end{abstract}

Keywords—new situation; arts design; education innovation

\section{INTRODUCTION}

In the increasingly competitive society, under the present situation of the social and economic booming period, in order to make the students adapt to the current social development and put their professional leaning into application, a new teaching mode, also a school-running mode of effective complement for traditional education system, combines theory with practice, class study with extracurricular activities, and school with enterprise, and it gets the recognition of more and more people in the education circle.

More and more students majoring in art design are enrolled in all colleges and universities and the employment of graduates suddenly gets grim, which is an important topic for the workers of art design education in colleges and universities who has thought about it in recent years. There are many factors that can influence the students' employment, but the acquisition of an ideal job for students is directly conditional on their basic professional skill, basic technical and basic professional knowledge learned in the college, which is also one of main factors for students to sign. Obviously, the improvement of teaching quality, cultivation of qualified design persons with ability and necessary teaching reform is an effective way to increase the student employment rate, with a proportional relationship between the two.

The ability-purposed teaching is promoted for art education, stressing on the cultivation of practical art design talents for social needs. To put learning into application, it requires the major of graduates can be closely linked with the public life. At the same time, we should make new thinking according to our own characteristics, to reform the education system, timely and properly adjust the teaching content and direction, and to establish a new education mode from art to application, from theory to practice, from manufacturing to creation, so as to meet the demand and development of the times and combine class study with extracurricular activities, and school with enterprise, making the students acclimatize themselves to their role as soon as possible. Certainly, this is also an effective way for students to promote the employment.

\section{ORganization OF THE TEXT}

\section{A. Characteristics of the subject}

From the point of view of design, art design is a discipline of strong practicality and wide application. To become a qualified art designer truly, the following qualities should be provided, such as unique imagination and creativity, correct aesthetic view and keen insight, and strong practice ability, all of which are essential elements. Then the appropriate reform in teaching will help to the development of students in the field of industry and provide them specific support.

The subject of art design is the combination of skill and art. Students can learn theoretical knowledge from class, but they must participate in practice to cultivate their hands-on ability, communication ability and operation ability. The teachers in charge of design class should guide the students to participate in social practice, to acquire the practice experience that can' $t$ be got from traditional classroom, laying the foundation for the work in the future.

The subject of art design is the integration of art and science, and the education of art design has its own characteristics, with many courses of skills, techniques, representation and practice, most of which is taught in unit. Compared with the curricula of arts and science, the subject has relatively concentrated teaching arrangement, and has more courses suitable for outdoor teaching, participating in social activities or directly entering into the enterprises. Therefore, it is necessary to make overall design of all the elements of practice teaching, based on the target of talent cultivation of art design education and the application of theory and method of system science, and to establish the teaching system of 
optimized structure and function in full accordance with the theatrical teaching system, through reasonable curriculum setting and reasonable allocation of all the links of practice teaching. As local colleges and universities, they have made exploration for the establishment and improvement of practice teaching system of art design education, according to the attribute of the subject, which fully proved the realistic significance to follow the rules of art design education, establish practice teaching system and cultivate talents needed for the society.

Especially in art design teaching, we should give students a take-off platform, to make them go towards the society from traditional classroom teaching, know both the design and the production process, have good ability to communicate with others, and become a qualified designer to meet the market needs.

\section{B. The current situation of art design education}

From the current situation, most of China's design education teaching activities still rest on the spread of knowledge in classroom, class and course, especially that the traditional teaching mode only pay attention to the cultivation of students for a professional skill, teaching in a ideal vision assumed by teachers.. Students are good at imitation, but lack of innovation; they are great in repeating the same things (design), but they are unable to create a better and more creative design work. This is resulted just because the current teaching activities of design education throw off the relevant practices of project cost accounting, construction management, bid and bidding etc, and there is no certain purpose and specific purpose pertinence in the study of students, of which the most serious problem is no participation of students in the practice. This brings the disconnection between theory and practice. While the disconnection between theory and practice destroyed the continuity of knowledge and skill learning, to make the students not put their learning into application, and further make their knowledge lagged relatively, so that the students are not up to the actual operation and do not know how to begin and do their design project, and even if they have good ideas and plans, they are overwhelmed and unable to express these ideas and plans.

1) The uncertainty of design education's purpose. However, China' s current art design education is basically a reproduction of other countries' teaching mode. They do not think deeply about their own education type features, nature and positioning, and design education' $\mathrm{s}$ ideas and concepts have not completely come into being. Under this case, we should orient market demand and make the development of hands-on skills as the core, which are the art design' s own feature and advantage.

2) Unclear feature of art design students training. Design education mode has always remained in the theoretical level, which causes some ignorance of practical skills. Thus training highly skilled talents is out of the question, so that design talents can not become "talents" in the true sense. However, higher art design education mainly aims at training hightechnique practical talents or named as high-skilled talents. Its feature and advantage lie in the trained talents with the characteristics of practicability, technicality and vocation, which is the universal features that design talents show, in which vocation is the most essential attribute. In view of this, we should require to stress the development of comprehensive vocational ability during the teaching activities of design education; the essential requirement of technicality make trained students develop long hand-on skills; practicability requires trained talents have the ability to get down to the grassroot, and can be employed, and can be kept in their career. At this point, the current art design education has not done enough.

3) Educational theory of art design is separated from practical teaching and the emphasis on practical teaching is not enough. In terms of creativity of design education, practice is the source of innovation, and it is generally known that scientific and technological innovations are derived from practice. At present, there exists the phenomenon that most of art design educational theory is disconnected with practical teaching, and there is lacks of causal relationship among various related courses, curriculum' s arrangement order and teachers, which lead to the low quality of teaching, and thus cause the development of the entire design education lag behind, and finally affect students' employment situation.

4) There is the phenomenon that the production is separated from education in art design major. Art design is a multidisciplinary, application-oriented major, and also can be said to be a combination of modern science and technology and cultural art. Becoming qualified talents of art design needs to combine theory with practice, unify proficient skills and strong innovation together and to make image thinking of the artistic creation and rational thinking co-exit. However, on the current condition of art design education, these aspects have serious disconnection. Therefore, advocating school-enterprise cooperation can effectively promote the combination of production and education, which makes students of art design major stand on the front and understand the front-line work, and thus having a systematic understanding from the design sample to the finished products.

\section{New trends of art design education and new ideas of design education}

From the perspective of characteristics of art design discipline, we should clearly understand the development trend of design education. The modern design education mode should be an open, society-oriented teaching structure of design education with the trinity of teaching, research and practice. Colleges and universities should be such a platform, which can provide students with theoretical guidance, and offer students environment and opportunities for practice to make them convert theory into hands-on skills in the specific operation.

In order to achieve this, we should strengthen the cooperation of production and education, and establish a new mechanism for cooperation and training of schools and enterprises, fully playing the role of design professional teachers in the teaching and cooperation, giving more practical 
hands-on opportunities to students, and providing students with a platform to start form school to society, which make design students apply their learned expertise with ease after they enter into society.

Art design major in Henan Institute of Education, with the overall objective of "applied talents" to meet economic and social development needs, has determined the talents positioning of art design from the design educational activities' original "artistic" designers to "market-oriented" designers. To this end, we should actively explore practical teaching mode of art design major in order to adapt to the local economic and social development and the Institute's reality. Through practice, a relatively complete practical teaching mode of "schoolenterprise cooperation" will be gradually formed. Through the reasonable curriculum and internships, practice and other practical teaching links, we can establish the practice teaching content system which is complementary with the theoretical teaching system, and focuses on cultivating innovative ability and entrepreneurial ability. On the basis of keeping the past school training, essentials internship, sketching practice and other practical teaching links, the "school-enterprise cooperation" practical teaching link has been added. The teaching mode of "curricular theory learning and extracurricular practical exercises" should be implemented to achieve the integration of learning and working, and classes and market.

\section{D. "Studio" mode under the influence of Bauhaus}

1) With renewal of ideas about "studio" mode under the influence of Bauhaus, to carry out studio teaching mode based on the design education and teaching practices.

In the new context, the art design education shall grasp the characteristics of the era, proceeding from the current educational realities in China and drawing lessons from successful examples at home and abroad, to actively promote the construction of studio cultivating mode in art design major according to local situations. Formed under the influence of German Bauhaus School of Design, the "studio" teaching mode in art design is currently the main design education mode in art colleges and comprehensive universities of Britain, France, Germany and other European counties, and it also has been on trial for years in some professional art design institutes in China. Generally, the "studio" teaching mode is directed by renowned teachers who have extensive experience in a certain design field, such as "the 7th Design Studio" led by professor Xiao Yong in Design School of China Central Academy of Fine Arts which is able to provide advanced design concept for students and maintain close contact with market trend, by using favorable advantages and through participation in social design projects directed by teachers, make students fully play their learning initiative to further understand the production process of design project, help them with the accumulation of design experience, effectively foster their spirit of teamwork, and via design practice ensure them to learn the knowledge and experience which cannot be acquired from the classroom simulation task, so as to lay a solid foundation for independently completing the design project after graduation.

2) Comprehensive qualities of the navigator in studio teaching mode

A critically important step to improve the effectiveness of integrated practice teaching is to build the stable practice teaching team with high quality. And only teachers with certain artistic theoretical accomplishment, unique innovative design capability, rich practical experience in art design and accurate aesthetic judgment can be competent for the practice teaching work and become the navigator in studio teaching mode. Therefore, the school shall adopt various forms to do a better job in teachers' training and recruiting, and meanwhile strengthen the teachers' business association with other universities and related design industries. The teachers also shall strengthen the knowledge update, timely grasp the new design trend in the market and improve the professional accomplishment as well as academic level.

Adhering to the idea of cultivating applied talents, promote the new concept of design education, through scientific approach, mobilize the combinations of production and study, theory and practice, art and technology, thereby forming the new design education mode based on combination between school and enterprise and interaction between classroom teaching and extracurricular teaching.

3) The reconstruction of objective system of talent cultivation in art design major aims to help students with their harmonious development of professional theory knowledge, practical ability and artistic comprehensive quality. In accordance with the "two-strong and one-high" (strong knowledge about basic theories, strong technique applying ability, broad knowledge background and high comprehensive quality) principle, reconstruct the structure of knowledge, ability and quality of the talents majoring in art design with the purpose of cultivating top-class applied talents possessed of "both theoretical knowledge and artistic innovation skills". At the same time, strengthen the cultivation of students' practical and creative abilities and attach great importance to the cultivation of literary accomplishment.

4) The reconstruction of process system of talent cultivation in art design major aims to form the "studio" teaching mode with combination involving production, teaching and research. Since the education process determines education results, the construction of education process takes on even more importance for the practice-emphasized art design major. Based on the step-by-step principle, gradually cultivate the art-oriented students into skill-oriented design talents by adding practical courses.

5) Establish the "vertically in-depth" system through the reformation of "studio" teaching mode and reconstruction of curriculum system. Specific to theoretical courses, proceeding from the structure of students' knowledge, ability and quality, rebuild the curriculum structure and update the teaching content based on the principle of "laying solid foundation, 
strengthening practice and highlighting innovation". While the practice teaching system in art design major is constructed through three modules including classroom training, task practice and studio practical training. Alternate the theoretical courses teaching with practice teaching in vertical and have them interpenetrated with each other in horizontal, thereby gradually forming the new design teaching system with dynamic integration of knowledge, ability and quality.

6) The effective integration of professional talent resources both inside and outside school aims to build reasonable and creative teaching staff teams. The shortage and unreasonable structure of teacher resources in art design major are currently the most common problems found in colleges and universities. Although external teachers may be able to fill the gaps, it' s quite difficult to manage them as well as to effectively control and guarantee the teaching time and teaching results, thus, external teachers cannot really solve the problems for most colleges and universities. However, the employment of mentors in "studio" mode breaches the limits on the class content and place of external teachers, giving studio teaching the maximum free space, mostly increasing the enthusiasm of teachers and students and allowing students to participate in the practice on the basis of theoretical courses learning.

\section{E. Construction of school-enterprise cooperative design education system guided by market demand}

To survive and develop, enterprises must rely on talents and universities must depend on the cultivation of talents who are competent for the job right after graduation and are highly competitive. In design education, energetically developing the skill-oriented education has become an important policy for the educational reform and development in China. Given this, majors desired by modern production as well as courses equal or similar to occupation post and post cluster shall be offered by the schools, which requires the universities, according to design industry development, corporate strategic adjustment and job changes and requirements, to properly adjust the specialty setting and teaching content based on the universities nature and orientation and cultivate large numbers of talents with sustainable development capacity. Therefore, the universities shall treat their own teaching work with a developmental view, take the initiative to maintain contact with enterprises and introduce the enterprise into classes during curriculum settings and teaching activities. In addition, dominant platforms shall be built and various practice ways shall be created.

1) New design education and teaching activities include building social practice platforms and creating various practice ways. The particularity of art design education determines its non-uniform patterns and standards around the world. Since China covers a vast geographic area and there have been many differences in regional culture and economic background from place to place as well as evident regional difference in education idea and school-running level, the practice teaching system in art design major shall be appropriately, reasonably and perfectly constructed based on the different provincial conditions and market demands, creating various practice ways, trying to get out of the collegebound practice teaching mode and combining with society and enterprises so as to make the art design practice integrated with market application and effectively enhance the employability of students in art design major.

2) Strengthen the construction of practice base and improve the efficiency of specialty practice teaching. Specialty practice is a practice teaching mode generally used in art design education and an important way to evaluate the teaching quality and improve the students' employability, which, however, due to the differences in regional economy, school-running conditions and practice teaching ideas, cannot be effectively implemented for a long time. In some specialties, because of the lack of practice base, students have to find internship units by their own during specialty practice. While such short-term procedure usually results in the rejection from enterprises for reason of disturbing the corporate internal operation or normal work order. There is another situation: after being accepted by some enterprises, the students are not allowed to participate in substantial design work, which makes them fail to apply what they have learned into the practice. Some internship units that students have found by themselves have nothing to do with their major, which makes the specialty practice the short-term part-time job. This specialty practice course without necessary internship fund and long-term feasible plan performs practically no function and definitely will not achieve the goal of cultivating talents with comprehensive practical ability. Therefore, it' $s$ imperative to combine with the local realities and strengthen the construction of practice base, make necessary capital investment, conduct necessary management and establish long-term cooperative relationship with enterprises, companies and other social units, so as to guarantee the practice teaching results of specialty practice course.

3) The cooperation between school and enterprise broadens the approach of students' comprehensive practice. Through interschool cooperation and mutual assistance, carry out the reformation and innovation of practice teaching contents and methods, give full play to respective discipline advantages and widen the field of design practice. At the same time, expand the scope of school-enterprise cooperation, combine the professional design curriculum with corporate design task project and try to appoint professional teachers and corporate designers as the project instructors, so as to offer students more opportunities to connect with the society and participate in the practice and further make students' design practice more operational and targeted.

4) Conduct social practice communication activities to effectively enhance students' comprehensive practical ability. By making full use of social resources, organizing the participation in competitions, exhibitions and holiday social practices as well as the collective participation in social design projects, create more practice opportunities for students, 
cultivate their comprehensive specialty literacy and artistic accomplishment and improve their abilities of design practicing, communication and team collaboration. In good time, introduce students' design works especially the excellent graduate design works to the market. For the design works with outstanding performance in artistry, designability and practicability, we will break the school-collecting habit and seek for suitable market and timing, which can not only improve the degree of social recognition for students' design works, realize the works' market achievement transformation but also effectively mobilize the students' enthusiasm for design practice.

\section{CONCLUSION}

All pamper imaginations with the purpose of cultivating skilled talents are the practice-based reformation, a new mode which aims to promote the theory teaching depending on practical skill operation through the combination of classroom and site. It allows students to participate in the corporate production and management while learning, and moreover makes students more social in nature and more aligned with the direction of social development, enabling them to meet demands of corporate development. With effective operation of practice teaching mode in art design major, the design education and teaching mechanism will be surely in good running condition, thereby guaranteeing that both university and enterprise give play to their initiative and achieve a winwin situation.

\section{REFERENCES}

[1] Zheng Yu, Study on University Students' Ability System, Press of University of Science and Technology of China, 2008.

[2] Jin Daiqiang, Cultural Industries and Art Design Education, Cultural Industries and Art Design Education, 2009.

[3] Chen Hanmin, Prospect of Art Design Education, Press of Southwest China Normal University, 2007.

[4] Zhang Zirui, Improvement of University Students' Innovation and Entrepreneurship, Science Press, 2008. 